УДК 504.055

\title{
ОЦЕНКА РАДИАЦИОННОГО ФОНА ПАРКОВ И СКВЕРОВ Г. СИМФЕРОПОЛЬ
}

Алексашкин И.В., Колесникова Е.Я., Дубас В.В., Зайцева Е.С. ФГАОУ ВО «Крымский федеральный университет имени В.И. Вернадского», г. Симферополь, Российская Федерачия e-mail:aligor@rambler.com

С каждым годом, перед мировым сообществом все более остро встает проблема негативного воздействия радиации на окружающую среду. Это обусловлено непрерывным ростом количества радиоактивных веществ как природного, так и техногенного происхождения, вследствие чего экологические системы Земли испытывают все большее влияние ионизирующего излучения.

Данная работа посвящена оценке радиационного фона основных и часто посещаемых парков и скверов города Симферополь. Для реализации поставленной цели были проведены замеры мощности экспозиционной дозы гамма-излучения, в результате чего по полученным усредненным значениям методом интерполяции построены карты.

Основной задачей авторов было не только проведение радиометрической съёмки территорий и составление радиоэкологических карт, но и выявление факторов негативного влияния ионизирующих излучений в определённых дозах на здоровье человека и природные сообщества, а также выявление доказательств, свидетельствующих о неизбежности существования ионизирующих излучений в живой природе.

Ключевые слова: радиация; радиационный фон; радиоэкологическое картирование; гаммаизлучение; плотность потока; экспозиционная доза.

\section{Введение}

Парки, скверы и другие зоны города являются потенциальными природными источниками радиации, которые создают около 70 процентов суммарной дозы, получаемой человеком от всех возможных источников. Так как, превышение радиационного фона всегда пагубно влияет на здоровье человека, радиоэкологический мониторинг среды является актуальным во все времена.

Целью данной статьи является оценка радиационного фона парковой зоны города и построение на основе полученных данных карт.

Для достижения поставленной цели решались следующие задачи:

1. Изучение природных условий исследуемых территорий;

2. Проведение радиометрической съёмки территорий;

3. Анализ радиационного фона зон отдыха города;

4. Выявление факторов воздействия ионизирующих излучений на здоровье человека;

5. Составление радиоэкологических карт на основании оценки.

Объектом исследования являются парки и скверы города Симферополь, а предметом - радиационный фон территорий парков и скверов города по мощности экспозиционной дозы гамма-излучения. Основными методами являются методы радиометрической съёмки, математико-статистический и картографический методы.

Существующие насаждения общего пользования г. Симферополя представлены 95 объектами зеленого строительства общей площадью 24048 га, в том числе: парки общегородского значения -5 (площадь 101.72 га), парки районного значения - 5 (площадь 26,31 га), скверы - 75 (площадь 78.72 га), бульвары 2 (площадь 1,12 га), набережные - 1 (площадь - 3,68 га), рощи - 7 (площадь - 28.93 га). 


\section{Материалы и методы}

Показатели интенсивности потока гамма-излучений фиксировались с помощью сцинтилляционного радиометра СРП-68-01. Данный измерительный прибор используются как радиометр для контроля внешней среды. Нижний предел дискриминации $\gamma$-излучения от 15 до 35 кэВ. Дискриминатор служит для отделения импульсов, амплитуда которых меньше некоторого заданного порога (шумы), и нормализации по амплитуде и форме импульсов, превышающих этот порог. Погрешность измерений $\leq \pm 10 \%$. Кроме того, контрольно-измерительные приборы СРП-68-01 используются для контроля продуктов сельского хозяйства и различных химикатов, для поиска радиоактивных руд по их гамма-излучению и для радиометрической съемки местности.

Для проведения радиометрической съемки были выбраны часто посещаемые места отдыха г. Симферополя (рис. 1), а именно: Детский парк; парк им. Ю.А. Гагарина; ботанический сад Таврической академии им. Н.В. Багрова; сквер им. К.А. Тренёва; парк культуры и отдыха им. Т.Г. Шевченко.

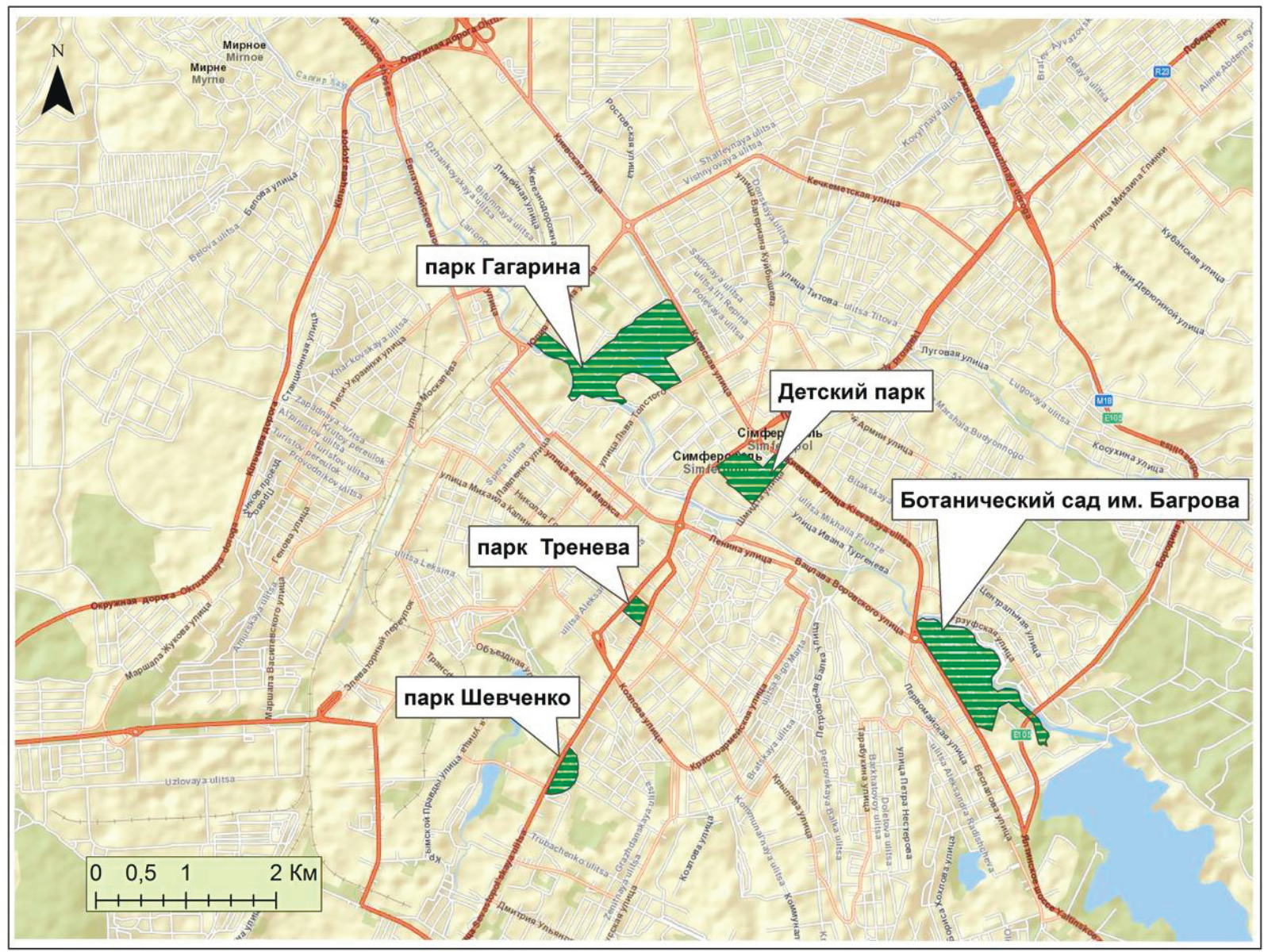

Рис. 1. Исследуемые территории города Симферополь

Данные радиометрической съемки представлены в виде средних арифметических значений по каждой исследуемой точке в виде таблицы 1. На основе полученных данных построены карты распределения гамма-излучения на территории парков и скверов г. Симферополя. 
Таблица 1.

Оценка радиационного фона по гамма-излучению

\begin{tabular}{|c|c|c|c|}
\hline $\begin{array}{c}\text { Зона радиоактивного } \\
\text { заражения }\end{array}$ & $\begin{array}{c}\text { Мощность эквивалентной дозы } \\
\text { гамма-излучения в мкР/час }\end{array}$ & $\begin{array}{c}\text { Мощность эквивалентной дозы } \\
\text { гамма-излучения в мкЗв/час }\end{array}$ & $\begin{array}{c}\text { Цвет на } \\
\text { карте }\end{array}$ \\
\hline Умеренное А & $7-13$ & $0.07-0,13$ & \\
\hline Сильное Б & $13,1-19$ & $0,131-0,19$ & \\
\hline Опасное В & $20,1-30$ & $0,201-0,3$ & $\geq$ ПДК \\
\hline Чрезвычайно опасное Г & 30,1 и выше & 0,301 и выше & \\
\hline
\end{tabular}

Интерполяция - это способ нахождения промежуточных значений величины по уже имеющемуся набору известных значений. Многим, кто сталкивается с научными расчетами часто приходится оперировать наборами значений, полученных экспериментальным путем или методом случайной выборки. Далее, как правило, на основании этих наборов данных требуется построить функцию, на которую могли бы с достаточной точностью попадать и другие значения набора данных. Данная задача называется аппроксимацией кривой. Разновидной аппроксимации, при которой кривая построенной функции проходит точно через имеющиеся точки данных, называется интерполяцией (Козлов В.Ф., 1991).

Для распределения территориального размещения точек измерений на карты исследуемых территорий была наложена сетка. В данной выборке точки расставлялись по правильной геометрической системе - в углах квадратов. Как пример представлена карта Ботанического сада им. Н. В. Багрова (рис. 2) (Методические указания к лабораторным работам..., 2009). Именно в этих узловых точках (40 точек) производился анализ.

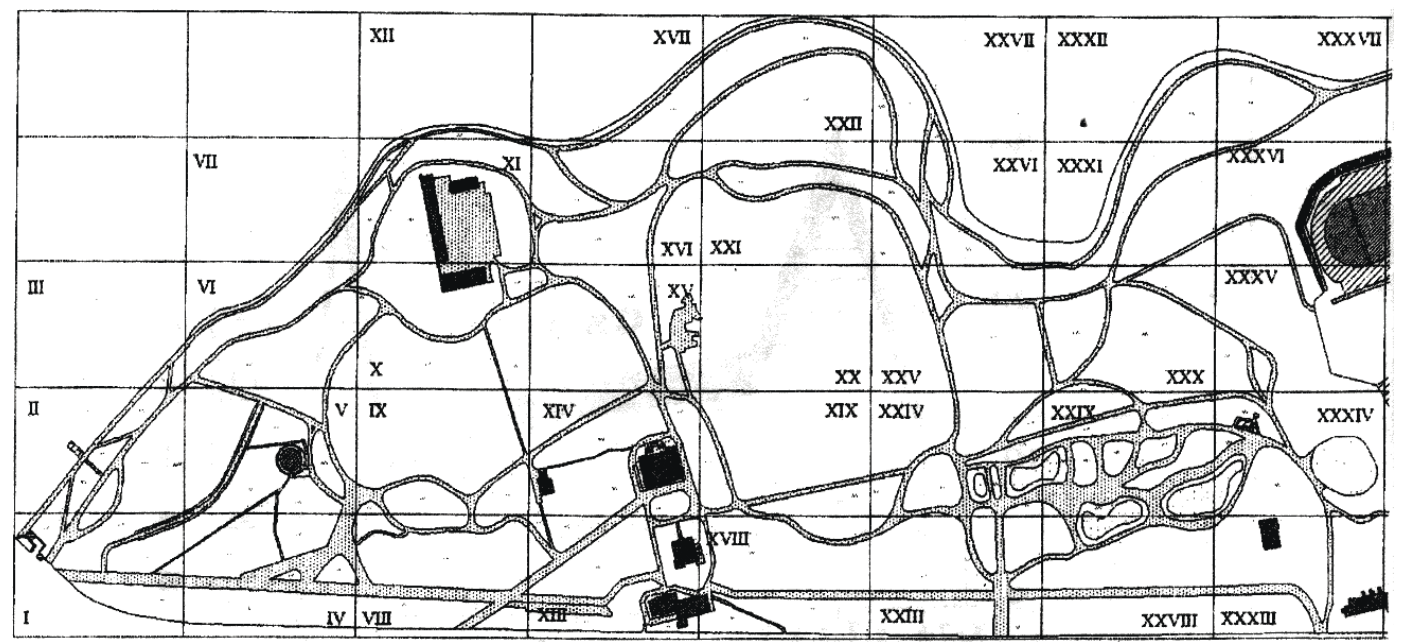

Рис.2. Точки измерений экспозиционной дозы в Ботаническом саду КФУ им. Н.В. Багрова

По степени заражения и возможным последствиям внешнего облучения на зараженной местности принято выделять четыре зоны: умеренного (зона А), сильного (зона Б), опасного (зона В) и чрезвычайно опасного (зона Г) заражения. Размеры зон заражения и уровни радиации на местности являются основными показателями степени опасности радиоактивного поражения людей.

Какой уровень радиации считается безопасным для человека? Данный вопрос имеет следующие ответы: доза получаемого человеком облучения в месте его проживания должна быть не больше 1 мЗв/год. Мощность эквивалентной дозы (МЭД) гамма-излучения на открытых участках должна находиться в пределах 0,3 мкЗв/час, 
если выше, то на ней объявляется чрезвычайная экологическая ситуация (Методические рекомендации по дозиметрическому контролю, 1990). Так как оценка радиационного фона по гамма-излучению проводилась в единицах - микрорентген в час (мкР/час), необходимо перевести значения ПДК - 0,3 мкЗв/час (система СИ) в мкР/час.

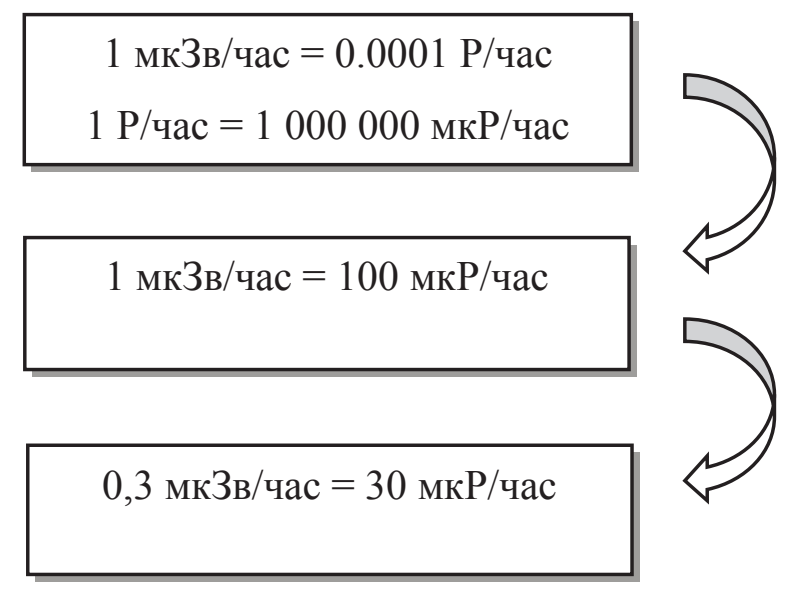

Таким образом, можно сделать вывод, что мощность эквивалентной дозы гаммаизлучения на открытых участках должна находиться в пределах 30 мкР/час - это безопасный уровень радиации для человека (СанПиН 2.6.1.2523-09).

\section{Результаты съемки и обсуждение}

В качестве опорного контрольного пункта была выбрана территория за Детским парком, расположенная в лесных насаждениях. В этот же день была проведена радиометрическая съемка в Детском парке, с расстоянием между точками измерения приблизительно 20-25 метров. В данном парке значительных отклонений от нормы не наблюдалось, в среднем значение интенсивности потока фотонного излучения колебалось от 7 до 11 мкР/час. Самая высокая интенсивность (15-17 мкР/час) наблюдалась около нового асфальтного покрытия детских велодорожек и расположенных рядом указательных знаков (рис. 3). Для интерполяции полученных данных использовался метод естественной окрестности (ArcMap 10.4.1.).

Далее съемка проводилась в парке им. Ю.А. Гагарина. Непосредственно через парк протекает река Салгир, не глубокая, обладающая небольшими каскадами по всей протяжённости. Вдоль реки проходит набережная, местами через реку «перебегают» небольшие мостики. Именно к этим мостикам ведут ступеньки из плит, интенсивность над которыми достигает значения свыше 25-29 мкР/час. В то время как общая интенсивность в парке колеблется около 7-9 мкР/час. Интенсивность потока фотонного излучения над плитами превышает норму, предположительно из-за происхождения известняка, который, возможно, в начале 1960-х годов был завезен из не самого безопасного карьера (рис. 4).

Позже была проведена радиометрическая съемка территории ботанического сада КФУ им. Н.В. Багрова. Средние показатели мощности дозы не превышали 14 мкР/час, что является нормой. Самая высокая интенсивность (23-24 мкР/час) наблюдалась около фасада Воронцовского дома (рис. 5).

В сквере им. К.А. Тренева максимальные значения интенсивности потока гаммаизлучения не превышали 12 мкР/час. А средние значения колебались от 8 до 9 мкР/час, что является самыми низкими и безопасными показателями относительно других парков и скверов, расположенных в г. Симферополь (рис. 6). 


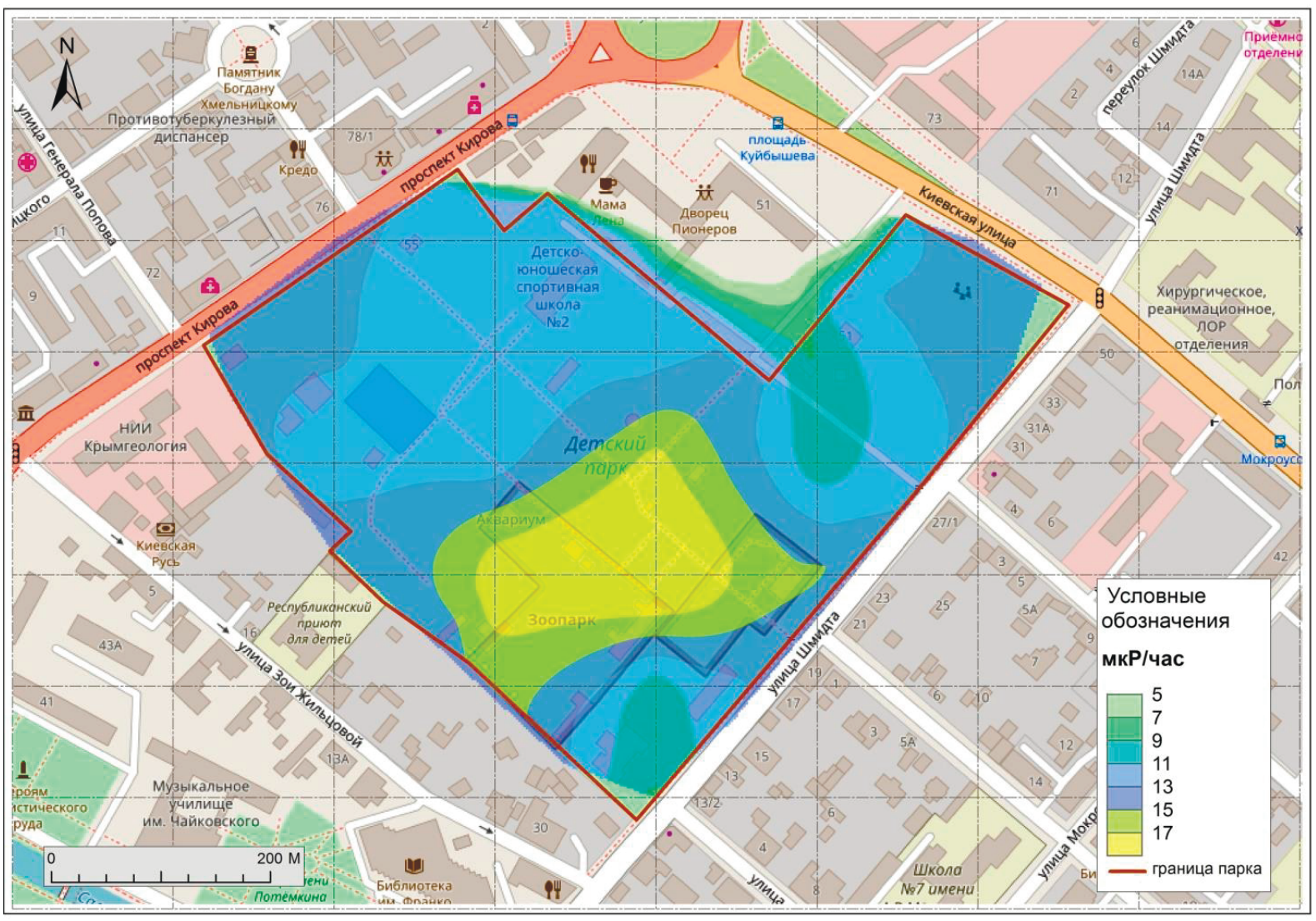

Рис. 3. Мощность экспозиционной дозы гамма-излучения в Детском парке

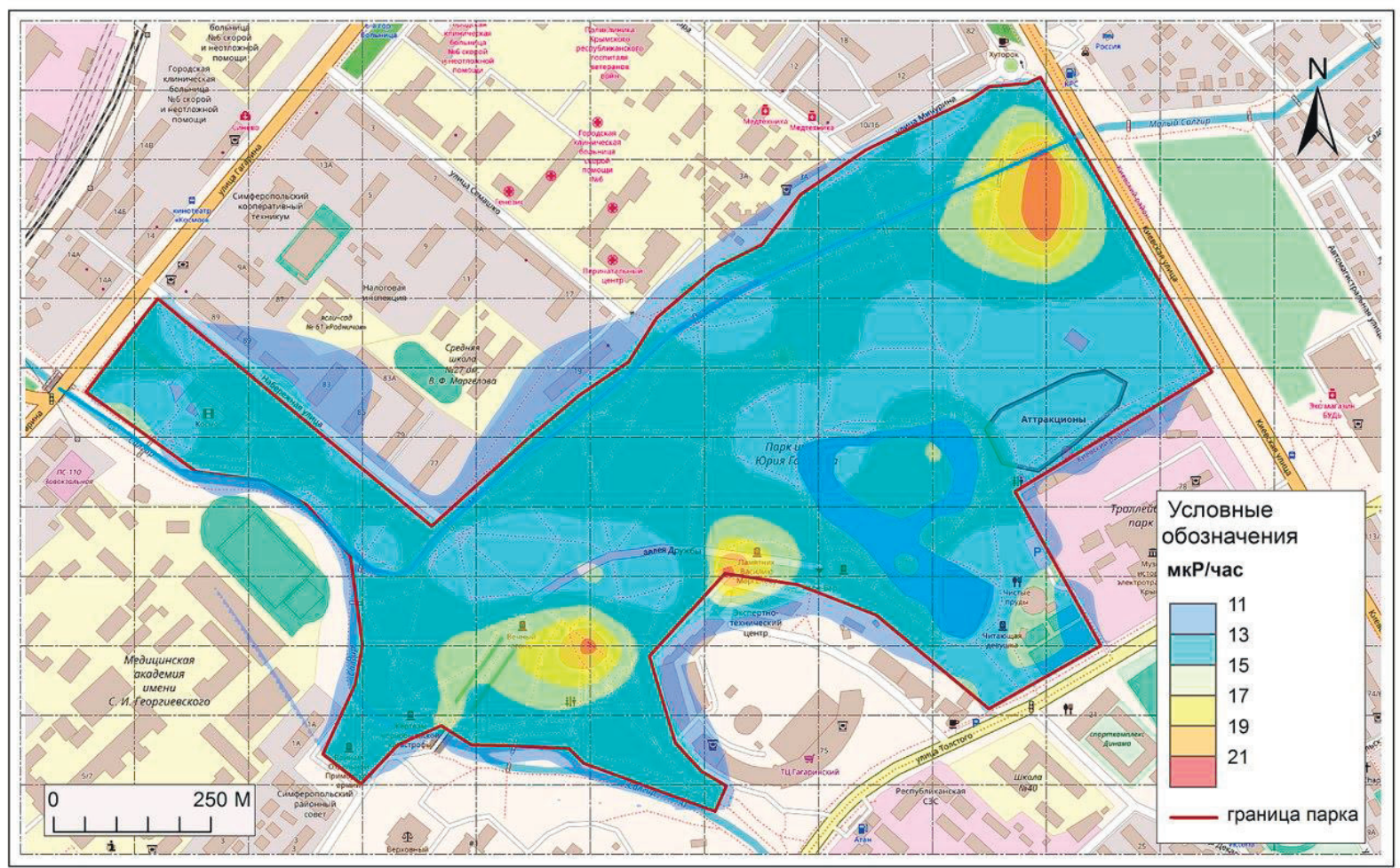

Рис. 4. Мощность экспозиционной дозы гамма-излучения в парке им. Ю. А. Гагарина

В парке им. Т. Г. Шевченко наблюдался резкий скачок показателей в районе центральной колоннады со стороны улицы Севастопольской и памятника Тарасу Шевченко, который установлен перед ней (рис. 7). 


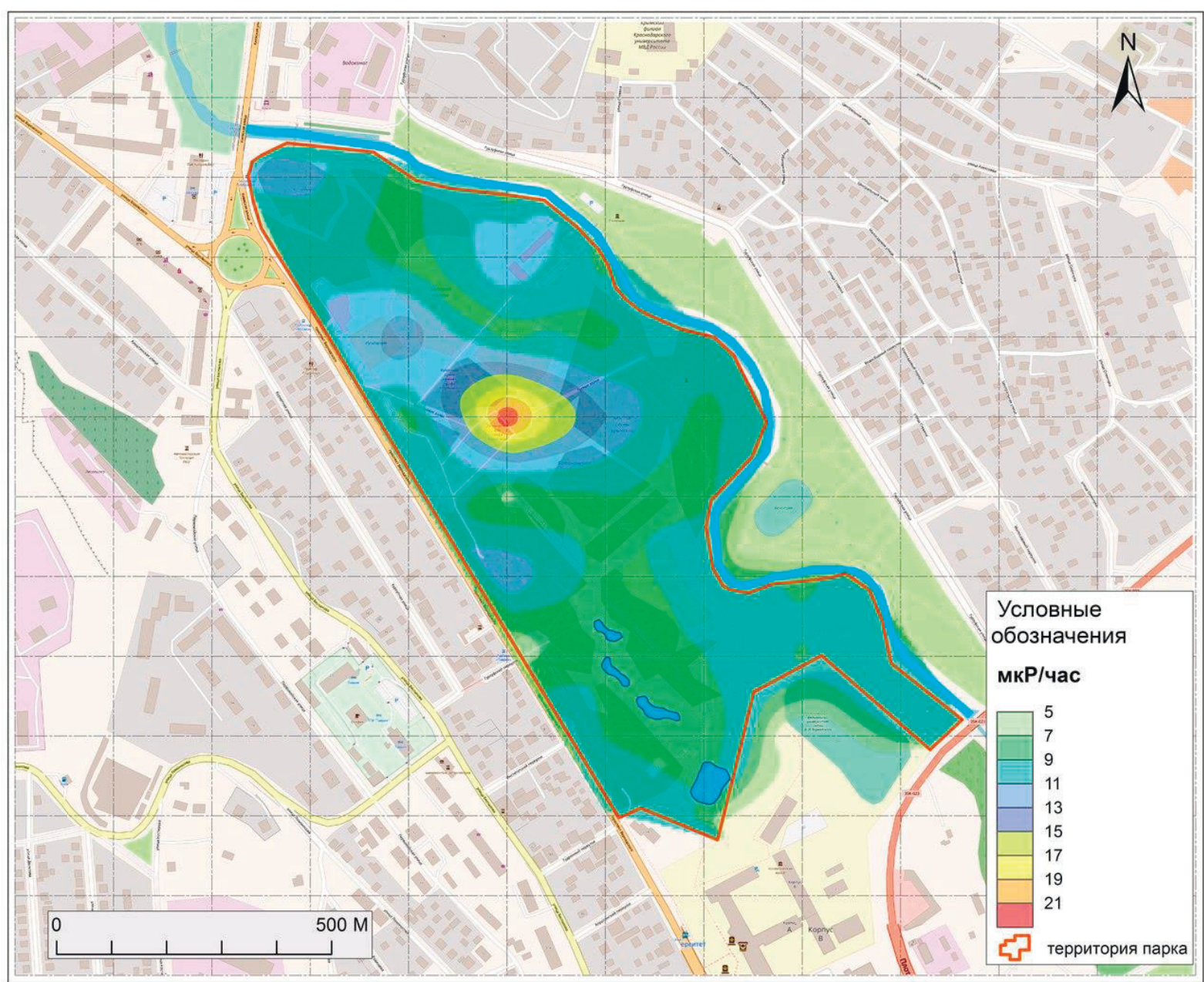

Рис. 5. Мощность экспозиционной дозы гамма-излучения, Ботанический сад им. Н.В. Багрова

Там интенсивность потока гамма-излучения достигала 21 мкР/час, в то время как по всему парку показания прибора колебались от 5 до 8 мкР/час (рис.8). Дело в том, что такие материалы как гранит, иногда могут иметь повышенные значения радиационного фона, это материал магматического происхождения, есть небольшая вероятность того, что он может содержать радиоактивные элементы, которые разлагаются на альфа, бета и гамма частицы излучения. Технически: нужно обратить внимание на гамма излучение, поскольку альфа и бета частицы не проникают далеко и абсорбируются самим материалом, а гамма лучи проникают значительно глубже.

\section{Выводы}

Изучение радиоактивности строительных материалов, а также создаваемого ими фона является актуальным в наши дни, так как в составе строительных материалов могут присутствовать уран 238, торий 232, калий 40 и другие радионуклиды, конечным продуктом распада некоторых из них является радон 222. Повышенное содержание радионуклидов свойственно калиевым и полевым шпатам, минералам глин и др.

Довольно сильно излучают магматические породы кислотного и щелочного состава (гранит, кварцевый диорит и т. д.), осадочные глины, особенно морские глубоководные. В меньшей степени - основные и ультраосновные породы (перидотит, габбро и др.). 


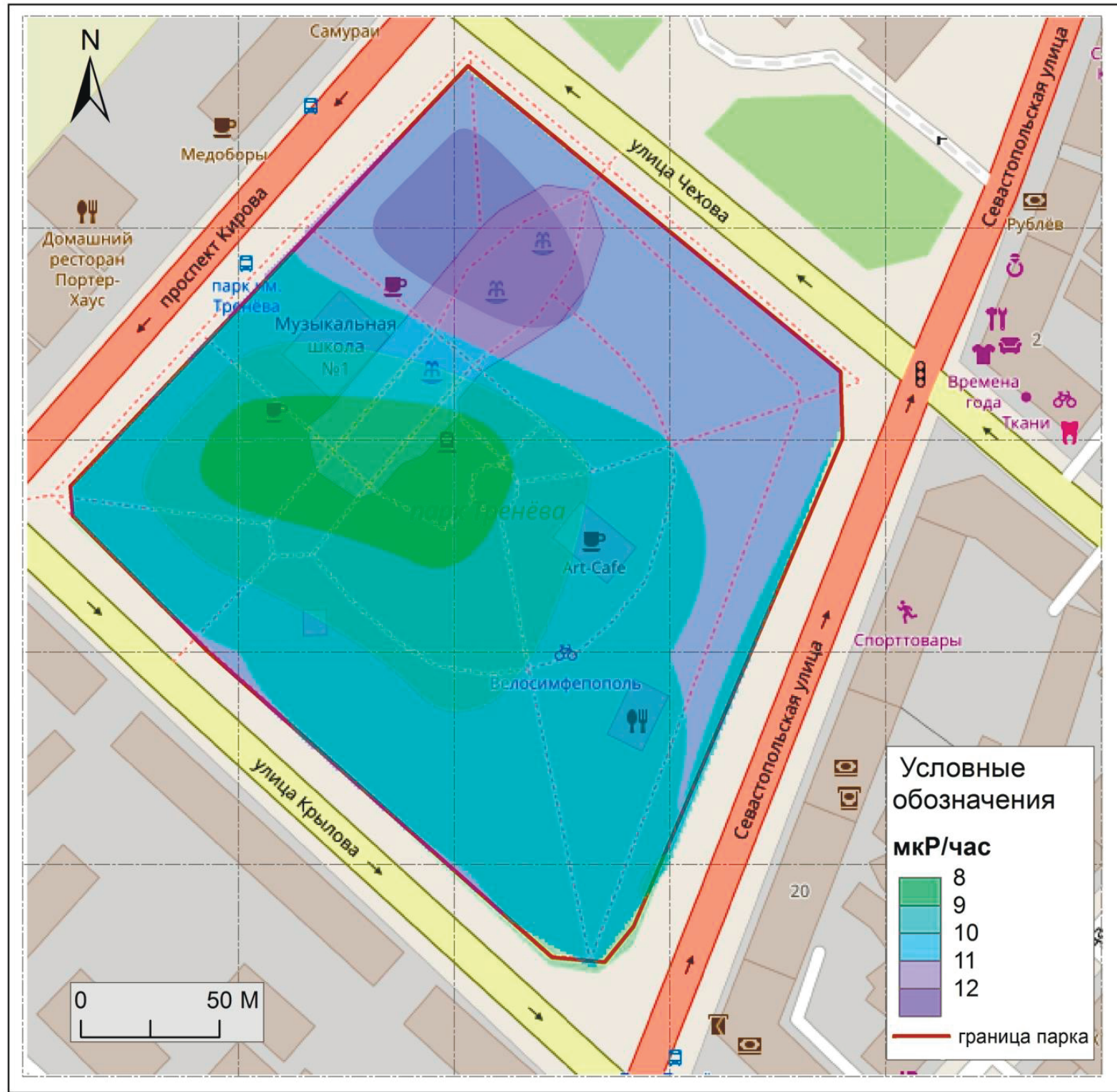

Рис. 6. Мощность экспозиционной дозы гамма-излучения, сквер им. К. А. Тренева

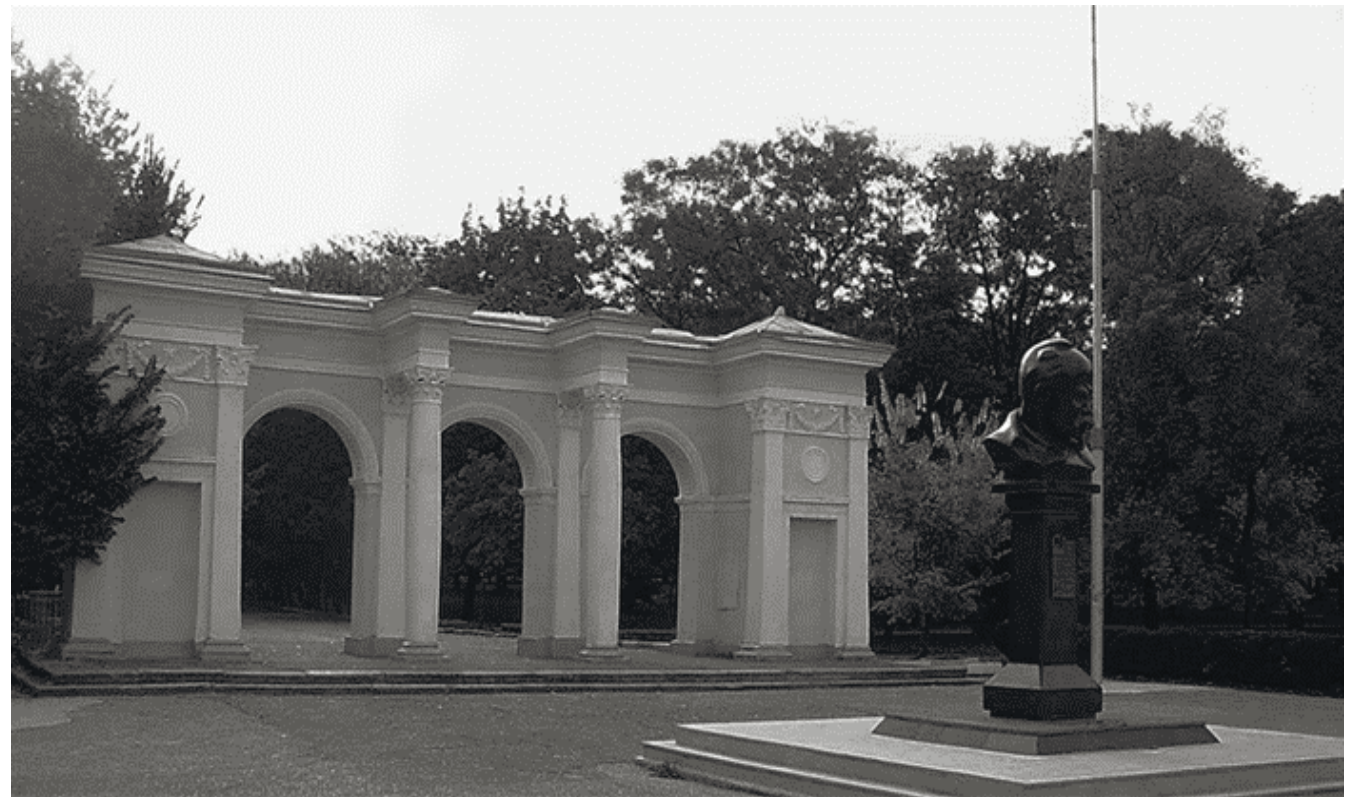

Рис. 7. Центральная колоннада и памятник Тарасу Шевченко 


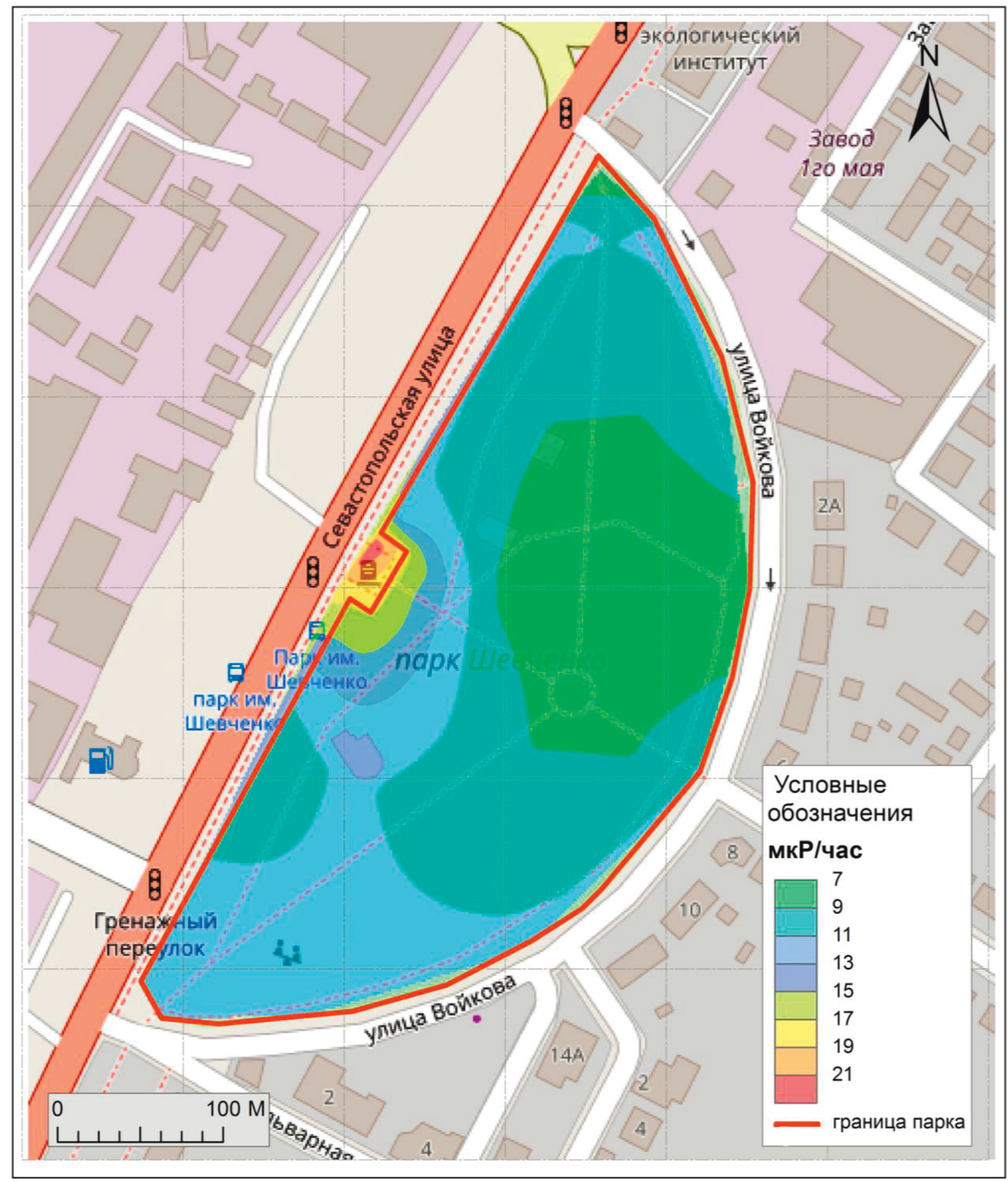

Рис. 8. Мощность экспозиционной дозы гамма-излучения в парке им. Т. Г. Шевченко

В ходе проведения радиометрической съемки парков и скверов города Симферополя, а также оценив радиационный фон по мощности экспозиционной дозы гамма-излучения можно выявить следующие закономерности:

1. максимальная мощность экспозиционной дозы не превышает 30 мкР/час;

2. распределение мощности экспозиционной дозы гамма-излучения связано с происхождением гранитных плит, а также с искусственно созданными насыпями;

3. материалы, из которых сделаны искусственные бассейны для каскада прудов, плиты для ступенек и памятники предположительно были в свое время привезены из 
карьеров Украины, с существующей вероятностью отсутствия соответствующей проверки. Так как интенсивность около них достигает значений около 25-29 мкР/час.

Как известно особенно сильно излучает гранит. Уровень его излучения составляет в среднем 25-30 мкР/ч, такие показатели прибора можно было наблюдать как раз около гранитных плит памятников и ступенек. То есть, излучение от гранита хоть и превышено, но не критично. Примечательно, что при нагревании радиоактивность гранита возрастает за счет интенсификации выделения из гранита радона. Об этом нужно помнить при установке памятников в парковых зонах города и облицовке зданий.

Подводя итог проведенной работы можно сделать вывод, что радиационный фон парков и скверов города Симферополя находится в пределах допустимых значений. Мощность эквивалентной дозы гамма-излучения на открытых участках не превышает 0,3 мкЗв/час (30 мкР/час). В то же время наблюдались незначительные отклонения скачки показателей мощности экспозиционной дозы в парке им. Ю. А. Гагарина и в парке культуры и отдыха имени Т. Г. Шевченко.

\section{Список литературы}

1. Козлов В.Ф. Справочник по радиационной безопасности / В.Ф. Козлов. - М.: Энергоатомиздат, 1991. - 352 с.

2. Методические указания к лабораторным работам по курсу «Радиоэкология» / Алексашкин И.В., Горбунов Р.В. - Симферополь: ТНУ им. В.И. Вернадского, 2009. $-36 \mathrm{c}$.

3. Методические рекомендации по дозиметрическому контролю / Академия наук УССР, Министерство здравоохранения СССР; А. Косинов, М. Коваль, А.А. Адаменко и др. - К.: Здоровье, 1990. - 40 с.

4. СанПиН 2.6.1.2523-09 «Нормы радиационной безопасности (НРБ-99/2009)». Введ. 2009-09-01 постановлением Главного государственного санитарного врача РФ №47 от 07.07.2009. - $70 \mathrm{c}$.

\section{ASSESSMENT OF THE RADIATION BACKGROUND OF PARKS AND SQUARES OF SIMFEROPOL}

Aleksashkin I.V., Kolesnik E.Y., Dubas V.V., Zaitseva E.S.

V.I. Vernadsky Crimean Federal University, Simferopol, Russian Federation e-mail:aligor@rambler.com

Every year, the world community is faced with the problem of the negative impact of radiation on the environment. This is due to the continuous increase in the amount of radioactive substances of both natural and man-made origin, as a result of which the earth's ecological systems are increasingly influenced by ionizing radiation.

This work is devoted to the assessment of the radiation background of the main and frequently visited parks and squares of the city of Simferopol. To achieve this goal, the power of the exposure dose of gamma radiation was measured, resulting in the obtained average values by interpolation maps were built.

The main task of the authors was not only to conduct radiometric survey of territories and preparation of radioecological maps, but also to identify the factors of the negative impact of ionizing radiation in certain doses on human health and natural communities, as well as to identify evidence of the inevitability of the existence of ionizing radiation in nature.

Key words: radiation; background radiation; radioecological mapping; gamma radiation; flux density; exposure dose.

Поступила в редакциюю 24.09.2018 2. 